\title{
Environmental Control of the Life Cycle of Dumontia contorta (Rhodophyta) Kept in Culture
}

\author{
H. Rietema and A. W. O. Klein \\ Department of Systematic Botany, Biological Centre of the University, P.O. Box 14,9750 AA Haren (Gr.), The Netherlands
}

\begin{abstract}
Tetraspores of Dumontia contorta (Gmelin) Ruprecht from the Isle of Man (UK) germinate directly after release into discoid or globular microthalli. Under long-day conditions $(16: \overline{8})$ and at higher temperatures $\left(20^{\circ} \mathrm{C}\right)$ these microthalli increase in diameter. However, under short-day conditions $(8: \overline{16})$ and at lower temperatures $\left(8^{\circ}, 12^{\circ}, 16^{\circ} \mathrm{C}\right)$ they give rise to macrothalli. This short-day effect is caused by photoperiodism, not by the lower light dosis. The macrothallus budding from the microthallus appears to be multiseriate in origin.
\end{abstract}

\section{INTRODUCTION}

Gametophytic and sporophytic thalli of Dumontia contorta (Gmelin) Ruprecht (= Dumontia incrassata [Müller] Lamouroux, cf. Abbott 1979) are morphologically identical. They consist of a basal radially expanded disc, growing over the substratum; from the disc sprout several cylindrical, hollow axes bearing irregularly placed laterals with the same construction as the axes. The disc (here termed microthallus, cf. van den Hoek et al., 1972) is perennial and gives rise to annual crops of upright macrothalli (Oltmanns, 1904; Rosenvinge, 1909; Dunn, 1917; Printz, 1926; Kilar and Mathieson, 1978)

Dumontia contorta is widely distributed in warm temperate and cold temperate regions in the northern hemisphere (Kjellman, 1883; Børgesen, 1903; Newton, 1931; Kylin, 1956; Taylor, 1957; Gayral, 1966; Ardré, 1970; Rueness, 1977; Abbott, 1979; van den Hoek, 1979). Field data about the seasonal occurrence suggest that macrothalli appear in autumn or winter, achieving maximum development during the winterspring period. In spring or early summer $D$. contorta becomes fertile and disappears, or only residual populations remain (Rosenvinge, 1909; Dunn, 1917; den Hartog, 1959; Kilar and Mathieson, 1978; Kristiansen and Pedersen, 1979). On the basis of extensive field studies of some New Hampshire populations of $D$. contorta, Kilar and Mathieson (1978) hypothesized that the appearance of macrothalli in autumn and winter is closely related to low temperatures and high nutrient concentrations. These authors further assumed that spores released in the spring-summer period did not germinate directly but persisted until autumn, although this assumption did not agree with observations of Rosenvinge (1909), Dunn (1917), and Jones and Dent (1971). The present study reports on growth and development of $D$. contorta kept in unialgal cultures from the Isle of Man.

\section{MATERIAL AND METHODS}

Tetrasporophytic plants of Dumontia contorta (Fig. 1) were collected from the intertidal zone at Port St. Mary, Isle of Man, in August 1979. At that time no gametophytic plants with carpospores were found. This agrees with observations made in late summer on D. contorta populations elsewhere (Dunn, 1917; Kilar and Mathieson, 1978). Tetrasporophytic plants were transferred in a cooler to our institute within $2 \mathrm{~d}$. Cutoff fertile segments of about $3 \mathrm{~cm}$ were rinsed several times in sterile seawater and incubated over night at $12{ }^{\circ} \mathrm{C}$, under long-day conditions $(16: \overline{8}), 2000$ lux, in small Petri dishes. The released spores were picked up with finely drawn pipettes and transferred to Petri dishes (diameter $10 \mathrm{~cm}$ ) whose bottoms were covered with glass squares $(25 \times 25 \mathrm{~mm})$ cut from microscopic slides. The original segments were again brought into a new, sterile medium. This procedure was carried out twice a day (at the beginning and end of a working day) for about $14 \mathrm{~d}$. Glass squares with developing spores in Petridishes without contaminating algae were transferred into small Petridishes (only 1 glass 


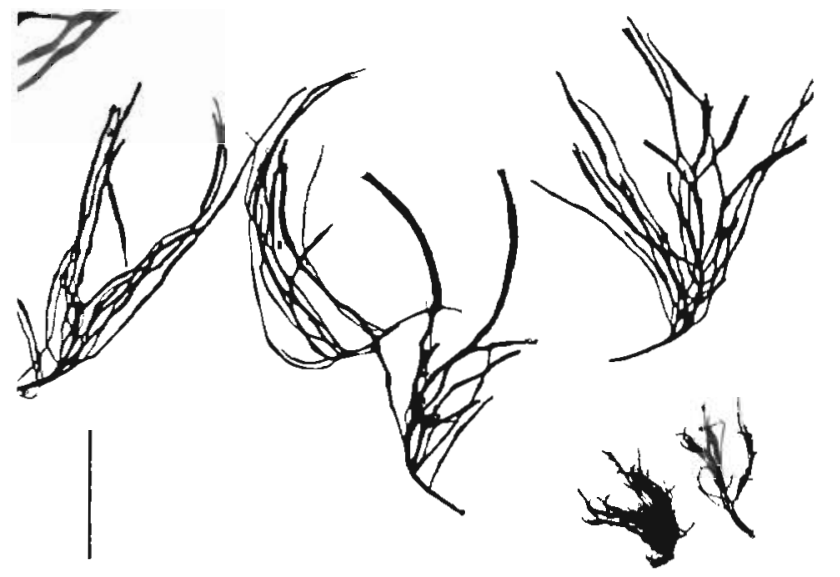

Fig. 1. Dumontia contorta. Fertile plants from nature. Large and small plants from a sheltered locality at Port St. Mary and an exposed locality at Port Erin, Isle of Man. Scale bar $=2 \mathrm{~cm}$

square per Petri dish) and kept at $12{ }^{\circ} \mathrm{C}$, under longday conditions $(16: \overline{8})$ and ca 2000 lux. In this way unialgal cultures were established. The number of germinating spores per glass square varied from 1 to ca 20. Experiments were carried out under the conditions given in Tables 1 and 2 , at $20^{\circ} \mathrm{C}$ under short-day conditions, at 2000 lux. A minor experiment was also conducted with tetraspores derived from a $D$. contorta plant growing on the wave-exposed breakwater of Port Erin in front of the Biological Station, Isle of Man. Here D. contorta plants were very small and thin (Fig. 1)

Small discs (diameter 300-500 $\mu \mathrm{m}$ ) of a rhodophycean species (Dumontia?) which occurred as small epiphytes on Laminaria saccharina growing in an intertidal rockpool (Port St. Mary, August 1979) were also cultured under laboratory conditions. Six discs were transferred to $12^{\circ} \mathrm{C}$, under long and short-day conditions, at 2000 lux.

All experiments were carried out in culture cabinets; light was provided by cool white fluorescent tubes (Philips T.L. 34). Different light intensities were obtained by varying the distance of the culture dishes to the light source. The temperature values given remained within $\pm 1.5 \mathrm{C}^{\circ}$, the light values within $\pm 5 \%$ lux. As culture fluid a Provasoli enriched seawater medium was used (Provasoli, 1968).

\section{RESULTS}

\section{Germination of Spores}

Released tetraspores of Dumontia contorta were about 38-40.5 $\mu \mathrm{m}$ in diameter. Almost all these spores attached themselves to the glass squares within a few minutes after being discharged into the Petri dishes. In

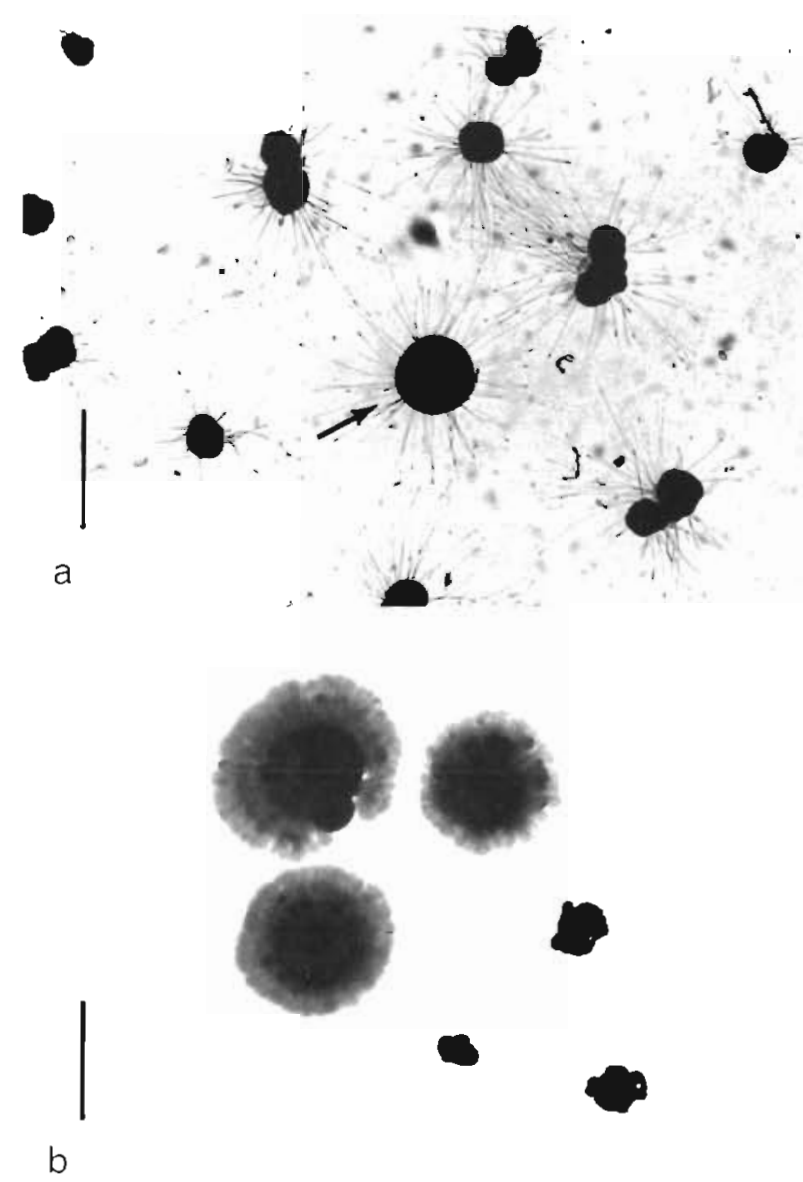

Fig. 2. Dumontia contorta. Microthalli grown in culture from tetraspores at $12^{\circ} \mathrm{C}$; long-day conditions; 2000 lux. (a) 4 week-old discoid microthallus (arrow) and equally old globular microthalli with hairs (scale bar $=1 \mathrm{~mm}$ ). (b) 26 week-old discoid and globular microthalli which failed to produce macrothalli under the culture conditions offered. Scale bar $=$ $5 \mathrm{~mm}$

a water stream they bent (and became tear-shaped) or burst. However, ca $3 \mathrm{~h}$ after inoculation they could easily be removed from the glass squares by employing a water stream. Obviously, the spores were then surrounded by a wall. Developing tetraspores grew into either attached discoid microthalli, or loose spherical microthalli (Fig. 2). Initial contact of the spores with the glass squares is apparently necessary for their development into discoid microthalli. Cultures in which the spores were loosened directly after attachment contained many spherical microthalli. Tetraspores developed within $24 \mathrm{~h}$ after release. During the first few cell divisions they increased slightly in size (Fig. 3a-e). Germinating spores which grew into discs were at first monostromatic, but later became polystromatic in the centre. Expansion of the discs occurred by means of marginal meristem. Coalescense of developing microthalli was observed frequently at 
various stages of development (Figs 3 and 5). Spherical masses of cells only rarely grew into discoid plants or developed elongated multicellular stolons which, in contact with glass squares, formed discs similar to those resulting directly from spores.

\section{Development of Microthalli}

The discs grew in diameter and gave rise - under environmental conditions mentioned below - to macrothalli. At first 1 macrothallus axis, sometimes 2 axes, arose from the centre of a disc. Thereafter many additional axes developed at some distance from the initially formed axes. The development of an erect axis was often announced by the appearance of a small light-coloured pit on a papilla. A bundle of filaments was formed, with all filaments growing together into an erect macrothallus, in these 'crater-like' structures (Fig. 4). In contrast to the slow growth of discs, the growth of the erect axis and its branches was rapid (Fig. 5). All branch initials of a macrothallus were already present on the very young macrothallus. During subsequent development the number of branches on an erect macrothallus axis did not increase. Only the distance between two successive branches and be- tween the lowest branch and the disc increased. The globular microthalli also grew in diameter. Each of them usually produced only 1 macrothallus; sometimes one more macrothallus or a small number of additional macrothalli were formed at a much later date.

The macrothalli developed into male or female gametophytes at $16^{\circ}$ and $12^{\circ} \mathrm{C}$ under long and shortday conditions, and carpospores were produced by some of the female gametophytic plants within 6 months after initiation of the gametophytic macrothallus plants. The production of spermatia by male plants and the release of carpospores by female plants led to the decline and ultimate death of the macrothallus phase. Only the discs remained alive.

\section{Influence of Environmental Conditions on the Initiation of Macrothalli}

The effect of day length and light intensity on the sprouting of macrothalli from microthalli was investigated by exposing microthalli to long-day conditions $(16: \overline{8})$ and short-day conditions $(8: \overline{16})$ in a combination with 4 different light intensities (4000, 2000, 1000 , 500 lux). This experiment was conducted with microthalli precultured during $32 \mathrm{~d}$ at $12^{\circ} \mathrm{C}$ in a daily

Table 1. Dumontia contorta. Influence of day length and light intensity on the formation of macrothalli on discoid microthalli. 12 ${ }^{\circ} \mathrm{C}$. Percentages of microthalli with macrothalli: $-0 \% ;(+) 0-10 \% ;+10-25 \% ;++25-50 \% ;+++50-75 \% ;++++75-100 \%$

\begin{tabular}{|c|c|c|c|c|c|c|}
\hline \multirow{2}{*}{$\begin{array}{l}\text { Day length } \\
\text { (h) }\end{array}$} & \multirow{2}{*}{$\begin{array}{l}\text { Light intensity } \\
\qquad \text { (Lux) }\end{array}$} & \multirow{2}{*}{$\begin{array}{l}\text { Number of } \\
\text { microthalli }\end{array}$} & \multicolumn{4}{|c|}{ Days after start of experiment } \\
\hline & & & 35 & 42 & 49 & 56 \\
\hline 16 & 4000 & 51 & - & - & - & - \\
\hline 16 & 2000 & 66 & - & - & - & - \\
\hline 16 & 1000 & 53 & - & - & - & - \\
\hline 16 & 500 & 50 & - & - & - & - \\
\hline 8 & 4000 & 69 & ++++ & ++++ & ++++ & ++++ \\
\hline 8 & 2000 & 79 & $++t+$ & ++++ & ++++ & $+t+t$ \\
\hline 8 & 1000 & 85 & +++ & ++++ & ++++ & ++++ \\
\hline 8 & 500 & 109 & - & $(+)$ & + & $+t$ \\
\hline
\end{tabular}

Table 2. Dumontia contorta. Influence of day length and temperature on the formation of macrothalli on discoid and globular microthalli. 2000 lux. Percentages of plants with macrothalli: $-0 \% ;(+) 0-10 \% ;+10-25 \% ;++25-50 \% ;+++50-75 \%$; $+++75-100 \%$

\begin{tabular}{|c|c|c|c|c|c|c|c|c|c|}
\hline \multirow{2}{*}{$\begin{array}{l}\text { Day length } \\
\text { (h) }\end{array}$} & \multirow{2}{*}{$\begin{array}{c}\text { Temperature } \\
\left({ }^{\circ} \mathrm{C}\right)\end{array}$} & \multirow{2}{*}{$\begin{array}{l}\text { Number of } \\
\text { microthalli }\end{array}$} & \multirow{2}{*}{$\begin{array}{l}\text { Morphology of } \\
\text { microthalli }\end{array}$} & \multicolumn{6}{|c|}{ Days after start of experiment } \\
\hline & & & & 32 & 39 & 46 & 56 & 62 & 70 \\
\hline 16 & 16 & 51 & discoid & - & - & - & - & - & - \\
\hline 16 & 16 & 58 & globular & - & - & - & - & - & - \\
\hline 16 & 8 & 44 & discoid & -- & - & - & - & $(+)$ & $(+)$ \\
\hline 16 & 8 & 65 & globular & - & - & - & -- & - & - \\
\hline 8 & 16 & 52 & discoid & - & + & +++ & $++t+$ & ++++ & ++++ \\
\hline 8 & 16 & 61 & globular & - & - & $(+)$ & $(+)$ & + & ++ \\
\hline 8 & 8 & 52 & discoid & - & +++ & ++++ & ++++ & ++++ & ++++ \\
\hline 8 & 8 & 69 & globular & - & ++++ & ++++ & ++++ & $++t+$ & ++++ \\
\hline
\end{tabular}




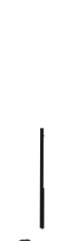

a

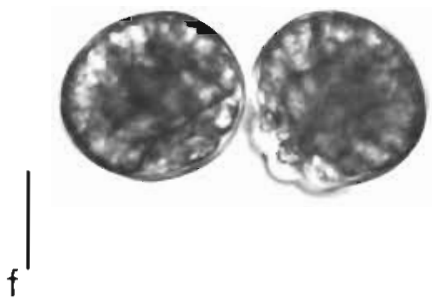

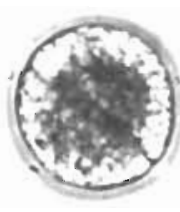

b

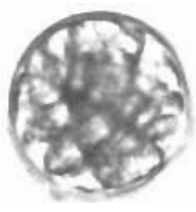

C

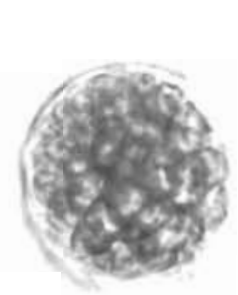

d

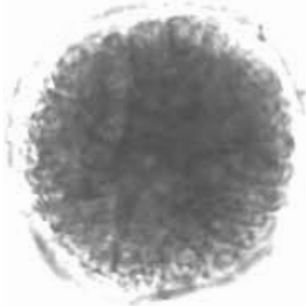

e

Fig. 3. Dumontia contorta. a-e: Germination of a tetraspore into a microthallus disc. $1 \mathrm{~h}$ (a), $24 \mathrm{~h}$ (b), $3 \mathrm{~d}$ (c), $7 \mathrm{~d}$ (d), and $11 \mathrm{~d}$ (e) after tetraspore release. $\mathrm{f}-\mathrm{h}$ : Coalescence of germinating tetraspores. $3 \mathrm{~d}(\mathrm{f}), 7 \mathrm{~d}(\mathrm{~g})$ and $11 \mathrm{~d}(\mathrm{~h})$ after tetraspore release. Scale bars $=25 \mu \mathrm{m}$
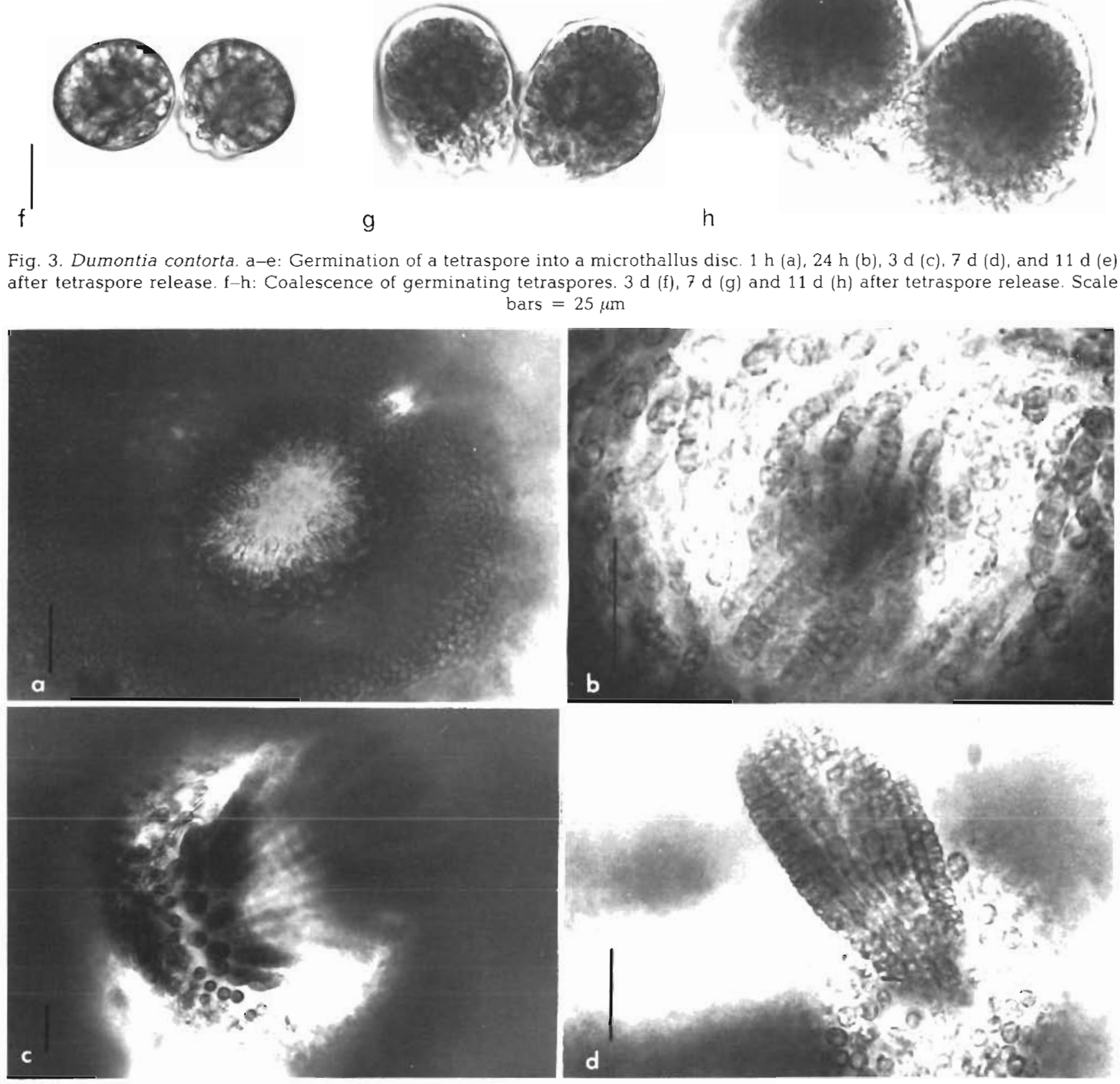

g

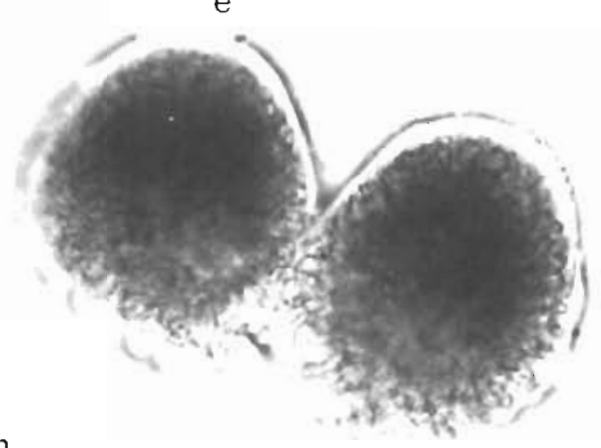

h

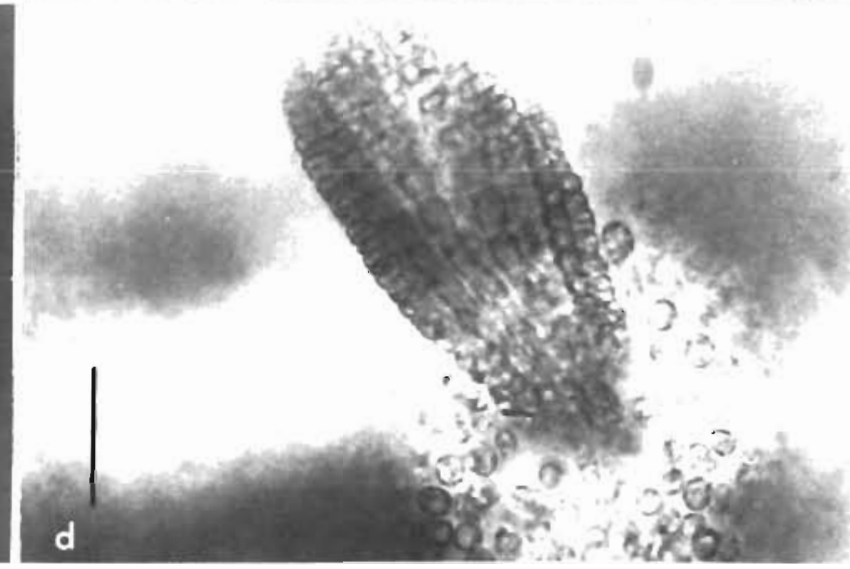

Fig. 4. Dumontia contorta. a-d: Initial stages in the development of a macrothallus. Papilla with only a light-coloured pit (a), with an occasional loose-lying filament (b), with a bundle of nearly parallel filaments (c), and with a bundle of parallel lying filaments, grown together (d). Scale bars $=25 \mu \mathrm{m}$ 


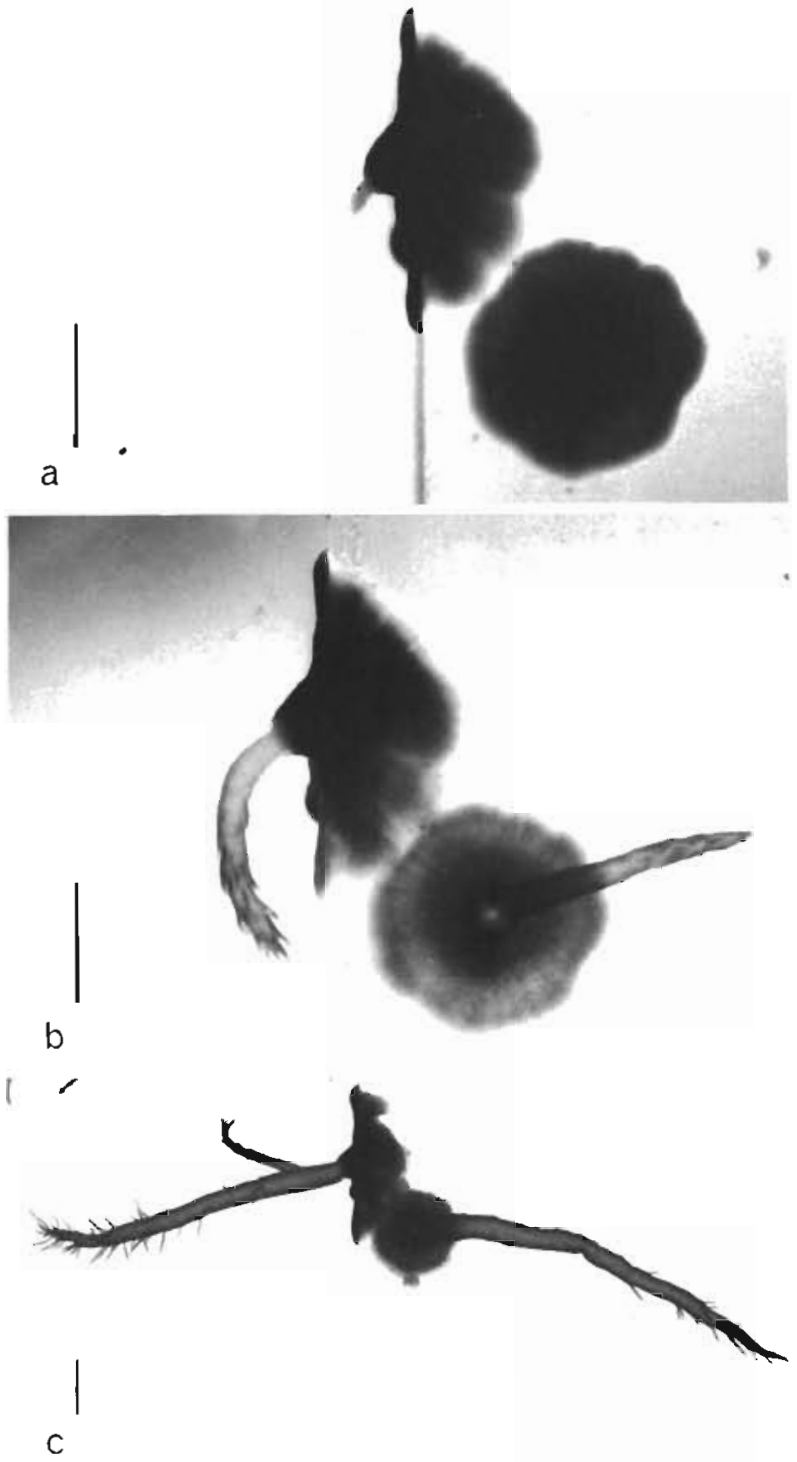

Fig. 5. Dumontia contorta. a-c: Development and growth of a macrothallus on discoid microthallı 5 weeks (a), 6 weeks (b) and 8 weeks (c) after transfer of ca 5 week-old microthalli from $12{ }^{\circ} \mathrm{C}$, long-day conditions, into $12^{\circ} \mathrm{C}$, short-day conditions, at 2000 lux. One microthallus seen in surface view, the other (lying on the margin of a glass square) partly in side view. Scale bars $=1 \mathrm{~mm}$

photoperiod of $16 \mathrm{~h}$ at a light intensity of ca 2000 lux. The results of this experiment are summarized in Table 1. Macrothalli were only formed under short-day conditions in all light intensities tested after a shorter or longer period of observation. After $35 \mathrm{~d}$ only lightcoloured spots were visible under 500 lux short-day conditions in the centre of the discs.

In another experiment the influence of long-day $(16: \overline{8})$ and short-day $(8: \overline{16})$ conditions on the sprouting of macrothalli from microthalli was investigated in
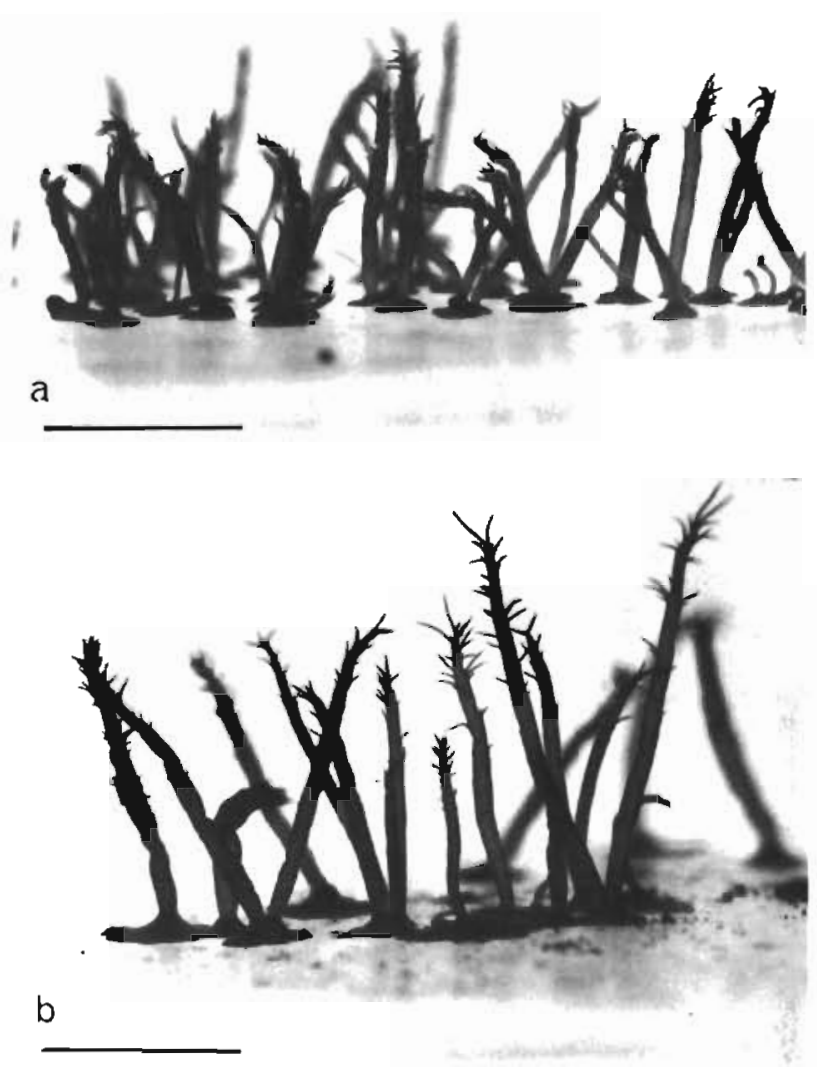

Fig. 6. Dumontia contorta. Macrothallus plants cultured for 10 weeks at $8{ }^{\circ} \mathrm{C}$ (a) and $16^{\circ} \mathrm{C}$ (b) under short-day conditions at 1000 lux. These macrothalli arose from microthalli which were 5 weeks older. Scale bars $=2 \mathrm{~cm}$

combination with 2 different temperatures $\left(8^{\circ}\right.$ and $16^{\circ} \mathrm{C}$ ). This experiment was conducted with microthalli precultured during ca $40 \mathrm{~d}$ in $12^{\circ} \mathrm{C}$ under longday conditions and at 2000 lux. The results of this experiment are summarized in Table 2. Only under short-day conditions did both the discoid and globular microthalli produce macrothalli. Globular microthalli kept at $16{ }^{\circ} \mathrm{C}$ under short-day conditions started to produce macrothalli later than discoid macrothalli kept under comparable conditions. Ten week old macrothalli kept at $8^{\circ}$ and $16^{\circ} \mathrm{C}$ under short condition and at 2000 lux are illustrated in Figure 6.

Another experiment demonstrated that neither discoid nor globular microthalli (ca 100 microthalli observed) gave rise to macrothalli at $20^{\circ} \mathrm{C}$ under shortday conditions at 2000 lux after a shorter or longer period of observation.

Also the discs derived from tetraspores of a small Dumontia contorta plant (Port Erin material) 
developed into macrothalli under short-day conditions. Macrothalli which sprouted from these microthalli revealed no differences in morphology with the macrothalli sprouting from the microthalli mentioned above. Discs isolated from Laminaria saccharina proved to be juvenile microthalli of $D$. contorta. Macrothalli were formed under short-day conditions, but not under long-day conditions.

\section{DISCUSSION}

The life history of Dumontia contorta is of the Polysiphonia type (cf. Dixon, 1973) and consequently comprises isomorphic gametophytes and tetrasporophytes. Both gametophyte and tetrasporophyte are winter-tospring annuals which pass the summer in the form of basal crusts (Oltmanns, 1904; Rosenvinge, 1909; Dunn, 1917; Printz, 1926; Kilar and Mathieson, 1978). These basal crusts are termed here 'microthalli', the erect thalli 'macrothalli' in accordance with van den Hoek et al. (1972). The present study shows that gametophytic macrothalli sprout from gametophytic microthalli under the combined influence of short-days $(8: \overline{16})$ and low temperatures $\left(8^{\circ}, 12^{\circ}, 16^{\circ} \mathrm{C}\right)$. This is the first example of an alga with an alternation of isomorphic gametophyte and sporophyte generations in which the interconversion of different developmental stages within one ploidy-phase is triggered by the photoperiod. In the Phaeophycea Scytosiphon lomentaria a morphological parallel of $D$. contorta, the macrothallus phase arises (either directly or via unizoids) from the crustose microthallus phase, also under the influence of short-day conditions and low temperatures, but in this case the entire life history consists of only one microthallus phase (in some populations the sporophyte phase) and one macrothallus phase (in some populations the gametophyte phase) (Wynne, 1969; Nakamura and Tatewaki, 1975). The macrothallus phase of $S$. lomentaria is also a winter-to-spring annual and is often found together with $D$. contorta macrothalli. The short-day effect observed in $D$. contorta was not caused by low daily light doses (Table 1). 'Induction of macrothallus buds' always occurred under short-day conditions, irrespective of light intensity, although at lower light intensities the macrothalli appeared later. However, 'light spots' (which precede the appearance of young macrothalli) were already visible at the centre of the discs after $35 d$, suggesting that macrothalli development had already been initiated but that their growth was slow owing to the low light intensity.

Based on extensive field studies Kilar and Mathieson (1978) assumed that the appearance of Dumontia contorta in autumn and the increase in size during winter and spring is primarily governed by seasonal changes in temperature and nutrient concentrations. Temperature certainly is another important factor which controls the seasonal appearance of $D$. contorta whereas macrothalli sprouted from microthalli at lower temperatures $\left(12^{\circ}, 16^{\circ} \mathrm{C}\right)$ and not at $20^{\circ} \mathrm{C}$. The combined influences of wide ranges of temperatures, day length and light conditions on the initiation and growth of the microthallus and macrothallus phase in both the gametophyte and tetrasporophyte generation of $D$. contorta are being investigated further at present.

Tetraspores of Dumontia contorta germinated in culture directly after release and grew into discoid microthalli or if unattached into spherical microthalli. The occurrence of juvenile microthalli of $D$. contorta in August (on Laminaria blades, Isle of Man) suggests that this also happens to spores in nature. These observations do not support Kilar and Mathieson's (1978) hypothesis that spores released in spring and summer germinate only in autumn. This hypothesis of Kilar and Mathieson attempts to explain the autumnal reappearance of $D$. contorta in nature.

The development of Dumontia contorta spores into cellular discs or spheres resembles the development of spores of Chondrus crispus (Chen and MacLachlan, 1972; Tveter and Mathieson, 1976); Gigartina stellata (Chen et al. 1974); Glolosiphonia capillaris (Edelstein, 1970) and Petrocelis franciscana (West, 1972). Early contact with a solid substrate is necessary for spores to develop into discs; otherwise they grow into spheres. The sprouting of macrothalli from the discs (or spheres) in the 4 latter species is not known to be under the influence of photoperiod.

Erect macrothalli of $D$. contorta arise from discoid microthalli. The development of a macrothallus starts by the formation of a bundle of filaments in a lightcoloured pit on a papilla. According to Kuckuck (in Oltmanns, 1904) only one of these filaments grows into a macrothallus. This could not be confirmed by our observations which strongly suggest that the whole bundle grows into the macrothallus.

Acknowledgements. The authors are much indebted to Professor Dr. C. van den Hoek for critically reading their manuscript.

\section{LITERATURE CITED}

Abbott, I. A. (1979). Taxonomy and nomenclature of the type species of Dumontia Lamouroux (Rhodophyta). Taxon 28: $563-566$

Ardré, F. (1970). Contribution à l'étude des algues marines du Portugal. Portugaliae acta biologica X: $1-423$

Borgesen, F. (1903). Marine algae of the Faeröes, botany of the Faeröes, Part II, Det Nordiske Forlag, Copenhagen

Chen, L. C.-M., Edelstein, T., MacLachlan, J. (1974). The life history of Gigartina stellata (Stackh.) Batt. (Rhodophyceae, Gigartinales) in culture. Phycologia 13: 287-294 
Chen, L. C.-M., MacLachlan, J. (1972). The life history of Chondrus crispus in culture. Can. J. Bot. 50: 1055-1060

Dixon, P. S. (1973). Biology of the rhodophyta, Oliver \& Boyd, Edinburgh

Dunn, G. A. (1917). Development of Dumontia filiformis. II. Development of sexual plants and general discussion of results. Bot. Gaz. LXIII: 425-467

Edelstein, T (1970). The life history of Gloiosiphonia capillaris (Hudson) Carmichael. Phycologia 9: 55-59

Gayral, P. (1966). Les algues des côtes Françaises (Manche et Atlantic), Deren \& Cie, Paris

Hartog, C. den (1959). The epilithic algal communities occurring along the coast of the Netherlands, North-Holland Publishing Company, Amsterdam

Hoek, C. van den (1979). The Phytogeography of Cladophora (Chlorophyceae) in the northern Atlantic Ocean, in comparison to that of other benthic algal species. Helgoländer wiss. Meeresunters. 32: 374-393

Hoek, C. van den, Cortel-Breeman, A. M., Rietema, H., Wanders, J. B. W. (1972). L'interprétation des données obtenues, par des cultures unialgales, sur les cycles évolutifs des algues. Soc. bot. Fr., Mém. 1972: 45-66

Jones, W. E., Dent, E. S. (1971). The effect of light on the growth of algal spores. In: Crisp, D. J. (ed.) Fourth European marine biology symposium, Cambridge University Press, Cambridge, pp. 363-374

Kilar, J. A., Mathieson, A. C. (1978). Ecological studies of the annual red alga Dumontia incrassata (O. F. Müller) Lamouroux. Botanica Mar. 21: 423-437

Kjellman, F. R. (1883). The algae of the Arctic Sea, K. Sv. Vet. Akad. Handl. 20; $350 \mathrm{pp}$

Kristiansen, Aa., Pedersen, P. M. (1979). Studies on life history and seasonal variation of Scytosiphon lomentaria
(Fucophyceae, Scytosiphonales) in Denmark. Bot. Tidsskr. $74: 31-56$

Kylin, H. (1956). Die Gattungen der Rhodophyceen, C. W K Gleerups Förlag, Lund

Nakamura, Y., Tatewaki, M. (1975). The life history of some species of Scytosiphonales. Sci. Papers, Inst. Algo. Res. Hokkaido Univ. 6: 57-93

Newton, L. (1931). A handbook of the British seaweeds, British Museum (Nat. Hist.), London

Oltmanns, F. (1904). Morphologie und Biologie der Algen, Vol. I, Gustav Fischer Verlag, Jena

Printz, H. (1926). Die Algenvegetation des Trondhjemsfjordes, Norske Videnskaps Akademi, Matem.-Naturvid. Oslo

Provasoli, L. (1968). Media and prospects for the cultivation of marine algae. In: Watanabe, A., Hattori, A. (eds) Cultures and collection of algae. (Proceedings of U.S.-Japan conference, Hakano, Sept. 1966) Jap. Soc. Plant Physiol. 1968: $63-75$

Rosenvinge, L. K. (1909). The marine algae of Denmark, contributions to their natural history, Vol. I, Rhodophyceae. Danske Vidensk. Selsk. Skrifter 7. Række Naturvidensk. og Mathem. Afd. VII, København

Rueness, J. (1977). Norsk Algeflora, Universitetsforlaget, Oslo

Taylor, W. R. (1957). Marine algae of the northeastern coast of North America, The University of Michigan Press, Ann Arbor

Tveter, E., Mathieson, A. E. (1976). Sporeling coalescence in Chondrus crispus (Rhodophyceae). J. Phycol. 12: 110-118

West, J. A. (1972). The life history of Petrocelis franciscana. Br. Phycol. J. 7: 299-308

Wynne, M. J. (1969). Life history and systematic studies of some Pacific North America Phaeophyceae (brown algae). Univ. Calif. Publ. Bot. 50: 1-88 